\title{
PUBLIC INVESTMENT IMPACT TO AGRARIAN SECTOR: COST - BENEFIT ANALYSIS
}

\section{Makhmudov Saidkarim Saidakhmatovich ${ }^{1}$, Jalilov Shohjahon Kholbozor ugli ${ }^{2}$, Bazarova Lobar Nuralievna ${ }^{3}$, Muratov Shukrullo ${ }^{4}$}

\author{
${ }^{1}$ Independent Researcher, Tashkent State Agrarian University, Tashkent, Uzbekistan \\ ${ }^{2}$ Independent Researcher, Assistant of the Department of Agribusiness and Investment Activity, \\ Tashkent State Agrarian University, Tashkent, Uzbekistan \\ ${ }^{3}$ Independent Researcher, Tashkent State Agrarian University, Tashkent, Uzbekistan \\ ${ }^{4}$ Doctoral Student (PhD), Tashkent Institute of Irrigation and Agricultural Mechanization Engineers, \\ Tashkent, Uzbekistan
}

Article DOI: https://doi.org/10.36713/epra8589 DOI No: 10.36713/epra8589

\begin{abstract}
In this paper examines the economic assessment of the investment funds in agriculture, sources and toward of public capital to agricultural activities, forestry and fisheries in Uzbekistan. Also, analyzed a profit taken from farm activity and the assessed public investment funds spent to agricultural activity. Factors impact to farm activity benefits have also been studied. The analysis used data from a social survey conducted on 44 farms in terms of distance not far from each other. It was found that investment funds at a rate of $1 \%(p<.01)$ plays a statistically significant role in increasing the profitability of farms from production activities. It is scientifically justified to increase the amount of investment funds involved in the activities of farms by 1 unit, which will increase the amount of income from activities by $22.6 \%$. In the case of an increase in the profit received from the production activities of farms, the investment amount is increased by 1 percent $(p<.01)$ statistically important significance was determined. It is scientifically justified to increase the amount of investment funds involved in the activities of farms by 1 unit, which will increase the amount of income from activities by $22.6 \%$.

KEYWORDS: profit, investment, investment funds, sources of investment, "robust (consolidation)", "strengthen".
\end{abstract}

\section{INTRODUCTION}

Investments ${ }^{1}$ are considered one of the main directions of economic development of foreign countries and their production, and investments in

\footnotetext{
${ }^{1}$ World Bank. 2007b. Philippines: agriculture public expenditure review. Technical working paper 40493. Washington, DC.
}

agriculture are considered as the decisive factor for economic growth, poverty reduction and food security ${ }^{2}$.

Investments play an important role in the continuous implementation of reforms in the socio-

\footnotetext{
${ }^{2}$ Lowder S. K., Carisma B., Skoet J. Who invests in agriculture and how much? An empirical review of the relative size of various investments in agriculture in low-and middleincome countries. -2012.
} 


\section{SJIF Impact Factor 2021: 8.013| ISI I.F.Value:1.241| Journal DOI: 10.36713/epra2016 \\ ISSN: 2455-7838(Online) \\ EPRA International Journal of Research and Development (IJRD) \\ Volume: 6 | Issue: 10 | October 2021 \\ - Peer Reviewed Journal}

economic spheres in our country, the development of industries and sectors, the sustainable development of integration processes between them, and the development of their attraction are carried out through an active investment policy ${ }^{3}$.

As a result, the volume of production of products in agricultural activities has affected the increase in quantity and quality, and by providing the population with agricultural products and processing industry with raw materials, the country is creating a basis for strengthening ${ }^{4}$ food security, increasing export potential.

However, in the recent years, although measures have been developed to improve the investment climate involved in agricultural activities and to guarantee the rights and interests of investors, to give them economic benefits, but in the volume of total investments in the sectors of the economy, the share of investments in agriculture is decreasing.

However, investment funds are important in ensuring the employment of the population of the rural area, diversifying the production activities of farms in the creation of a production chain, forming the activities of diversified farms. However, today, a significant part of the investment allocated to agricultural activities is being spent on improving the reclamation of irrigated crop areas. As a result, during 2008-2017, the water supply of more than 1.7 million hectares of irrigated land and the improvement of the land reclamation situation of 2.5 million hectares of land were achieved. ${ }^{5}$.

Investments in the production of agricultural products and the achievement of food security goals have been studied by several scholars. Economists point out that it was impossible to achieve financial stability and improve the sector economy without attracting huge volume of investment in agriculture ${ }^{6}$.
"The state support fund for Agriculture" was established in order to ${ }^{7}$ finance the sectors of the agrarian sector, ensure price stability in the domestic market, create a high value-added chain, implement a wide range of market principles in the development, production, purchase and sale of products. In this way, it is planned to cover part of the interest rate on loans allocated to support the activities of cotton, grain and vegetable growing in clusters and farms. The establishment of this system will have own impact on strengthening the relationship between production and distribution of material and technical resources in all conditions, especially during the pandemic, the efficiency of market infrastructure, as well as sustainable growth of agricultural activity, reducing inequality between manufacturing and processing industries.

It is important to make an economic assessment of the relationship between agricultural profits and investments in or involved in main activities and the factors that affect them.

The aim of this scientific article is to develop scientific proposals and recommendations based on an economic assessment, which affects the relationship between the profit from the activities of farmer farms and the investment funds involved.

\section{MATERIALS AND METHODS}

In this scientific article, initially, the annual statistical data of the Republic of Uzbekistan and the main economic indicators that characterize financing of the activities of the agrarian sector of the economy from 2013 to 2020, the changes in investment funds included in agricultural activities were studied.

Although the agricultural crop areas in Uzbekistan have decreased by an average of 4-5 percent over the past 5 years, the value of investments in agricultural, forestry and fisheries has increased significantly over the years 2014-2020 (Fig. 1).

\footnotetext{
Makhmudov S. Investitsiyalarni moliyalashtirishda investitsion muhitini takomillashtirish. Arxiv nauchnyx issledovaniy. 2020. - T. 35.

4 Yusupov M. Markazlashgan davlat investitsiyalari va maqsadli dasturlari orqali qishloq xo ‘jaligini rivojlantirishning ustuvor yo'nalishlari. Arxiv nauchnyx issledovaniy. - 2020. №. 10 .

${ }^{5}$ O`zbekiston Respublikasi Prezidentining Farmoni. Qishloq xo'jaligida yer va suv resurslaridan samarali foydalanish chora-tadbirlari to'g'risida. PF-5742-son. 17.06.2019

${ }^{6}$ Murtazaev O., Axrorov F. Qishloq xo'jaligi iqtisodiyoti. Ilm Ziyo, - Toshkent. 2017
}
7 O‘zbekiston Respublikasi Prezidentining Farmoni. O‘zbekiston Respublikasi moliya vazirligi huzuridagi qishloq xo'jaligini davlat tomonidan qo'llab-quvvatlash jamg'armasi faoliyatini takomillashtirish to ' $\mathrm{g}^{\text {'risida. }} \mathrm{PF}-6179$ - son. 26.02.2021. https://lex.uz/docs/5309649 -




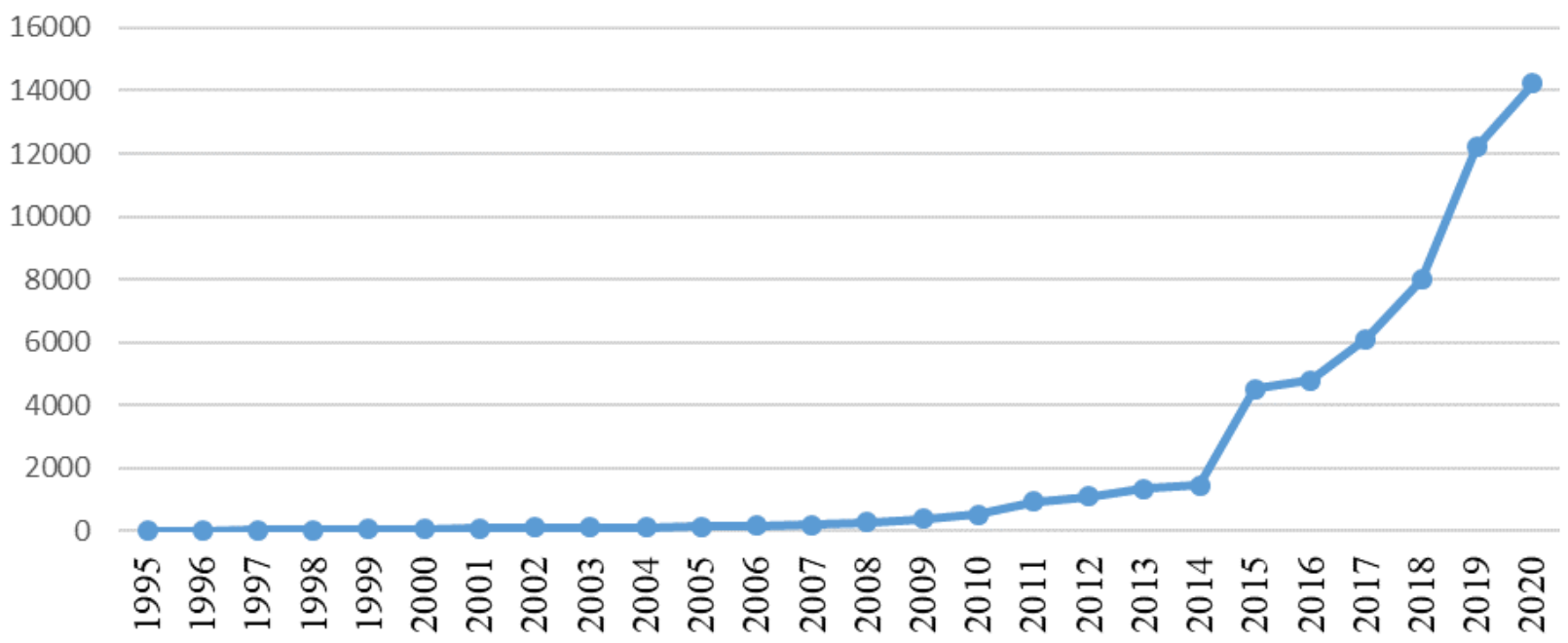

$\rightarrow$ Investment in fixed capital, billion soums

Figure 1. Investment in the fixed capital, billion soums

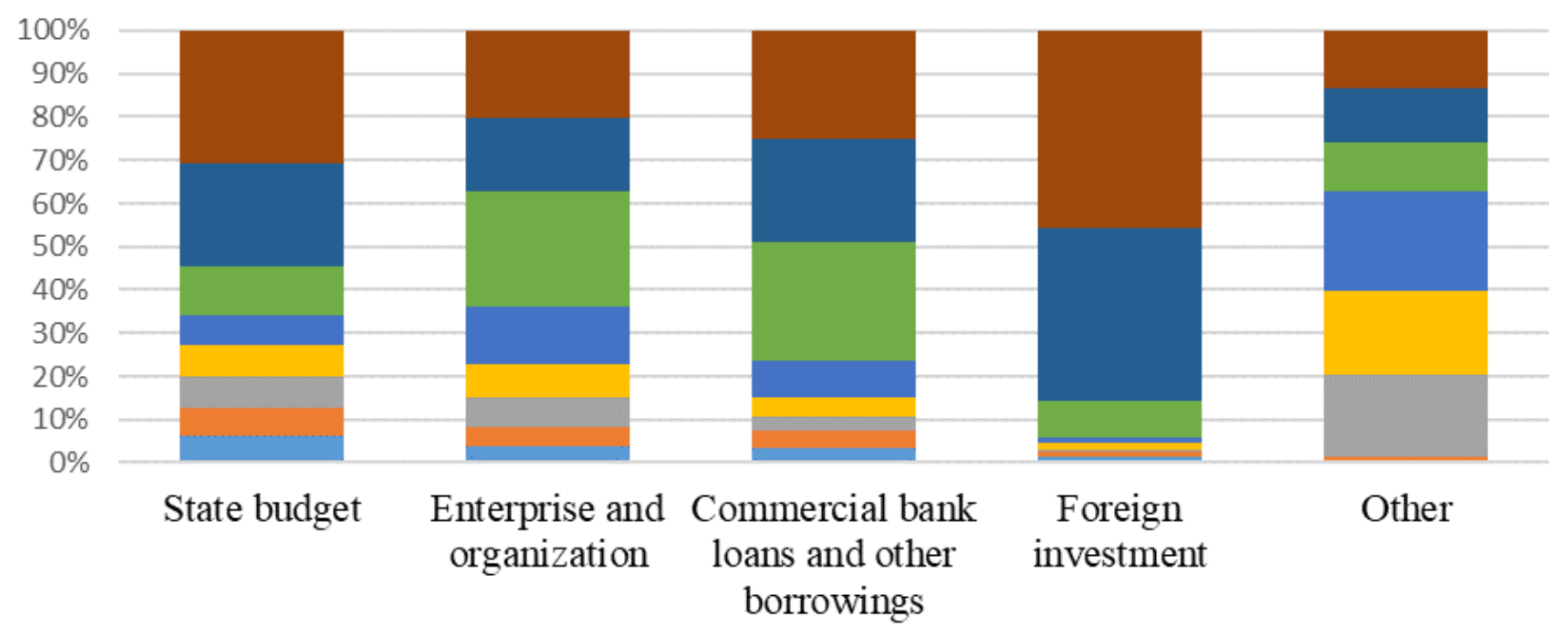

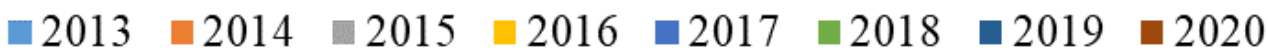

Figure 2. Investment sources included fixed capital, \%

In 2013-2014, if the average 35 percent of the investments in the main capital was accounted for by the budget of the Republic, the average 40-42 percent for the period of 2019-2020 was accounted for by foreign investment. However, although the value of agricultural, forestry and fisheries products (Fig. 3) has increased, the share of Agriculture in gross domestic product [GDP] has been in the trend of decline from 2017 to 2020 years. However, this was due to an increase in the share of other economic sectors in gross domestic product GDP. 


\section{EPRA International Journal of Research and Development (IJRD)}

70

60

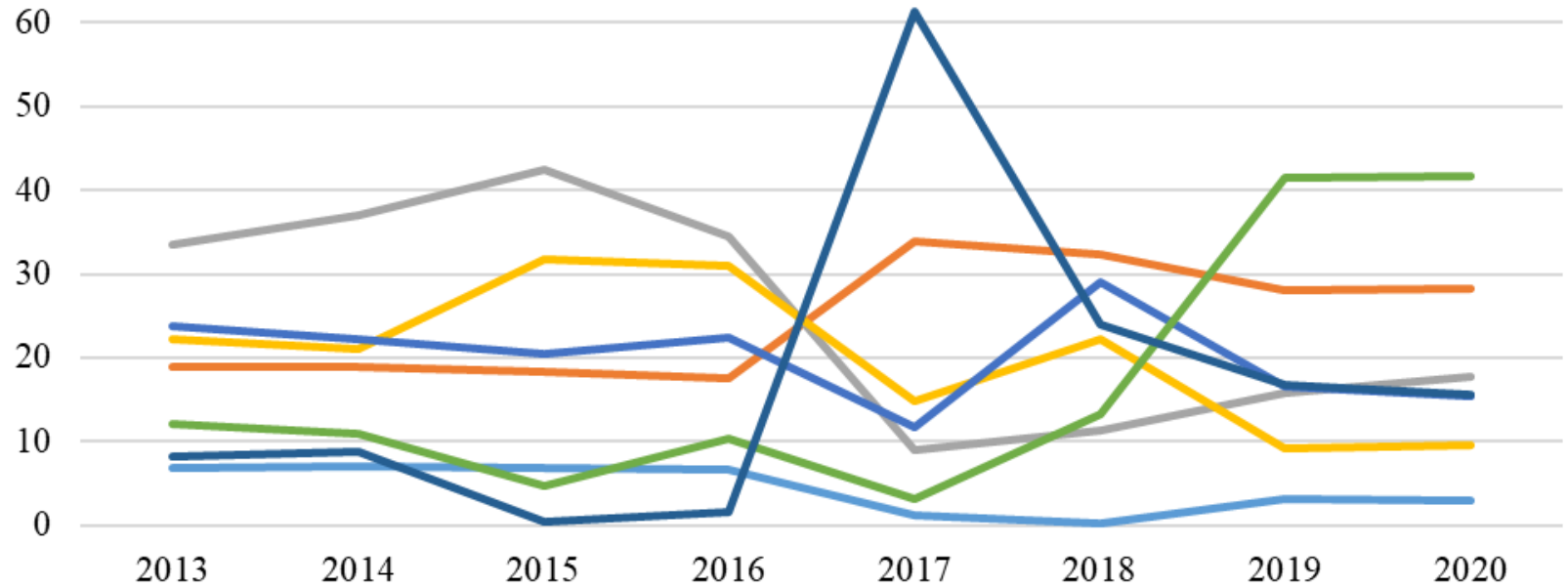

Growth rates of gross agricultural output

Share of agriculture in gross domestic product [GDP]

Financing from the budget of the Republic

Financing from the account of funds of the enterprise and the organization

Financing from commercial bank loans and other borrowed funds

Foreign investments

Financing from the account of other funds

Figure 3. The main economic indicators in the activities of agriculture, forestry and fisheries and the change of investment sources in which the main capital was invested, \%

In our scientific research work, a social survey was conducted on 2 farms in Pastdargom and Akdarya districts (Fig. 4) located in the Zarafshan River area of Samarkand region to evaluate the relationship between farm profits and investment as well as the economic factors affecting it.

The social survey was conducted in 44 farmer farms, of which 19 or 43,1 percent are multi-sectoral farmer farms (Table 1), while the main activity of which is the farms that grow plant products is $\mathbf{5 2 . 2}$ percent.

In the social survey, this indicator was not obtained because the heads of farms are the same gender, male. Farm managers had secondary special, higher, and post-graduate education, expressed in 1:2:3 quality values, respectively. On average, 82 percent of farmers received secondary special and higher education.

In the data of the questionnaire, investment funds in profit derived from the activities of farmer farms were expressed in decimal logarithms (ln) in order to eliminate "bias" in the economic assessment of the factors influencing them, as well as quantitative indicators (profit, crop area, labor resources, investment funds, and expenditure expenditure).

For an economic assessment of the relationship between these indicators, a linear regression method was used, by using the STATA16 software package. The results of the analysis were obtained using the command "robust (reinforcement)" to strengthen the relationship between variables. 


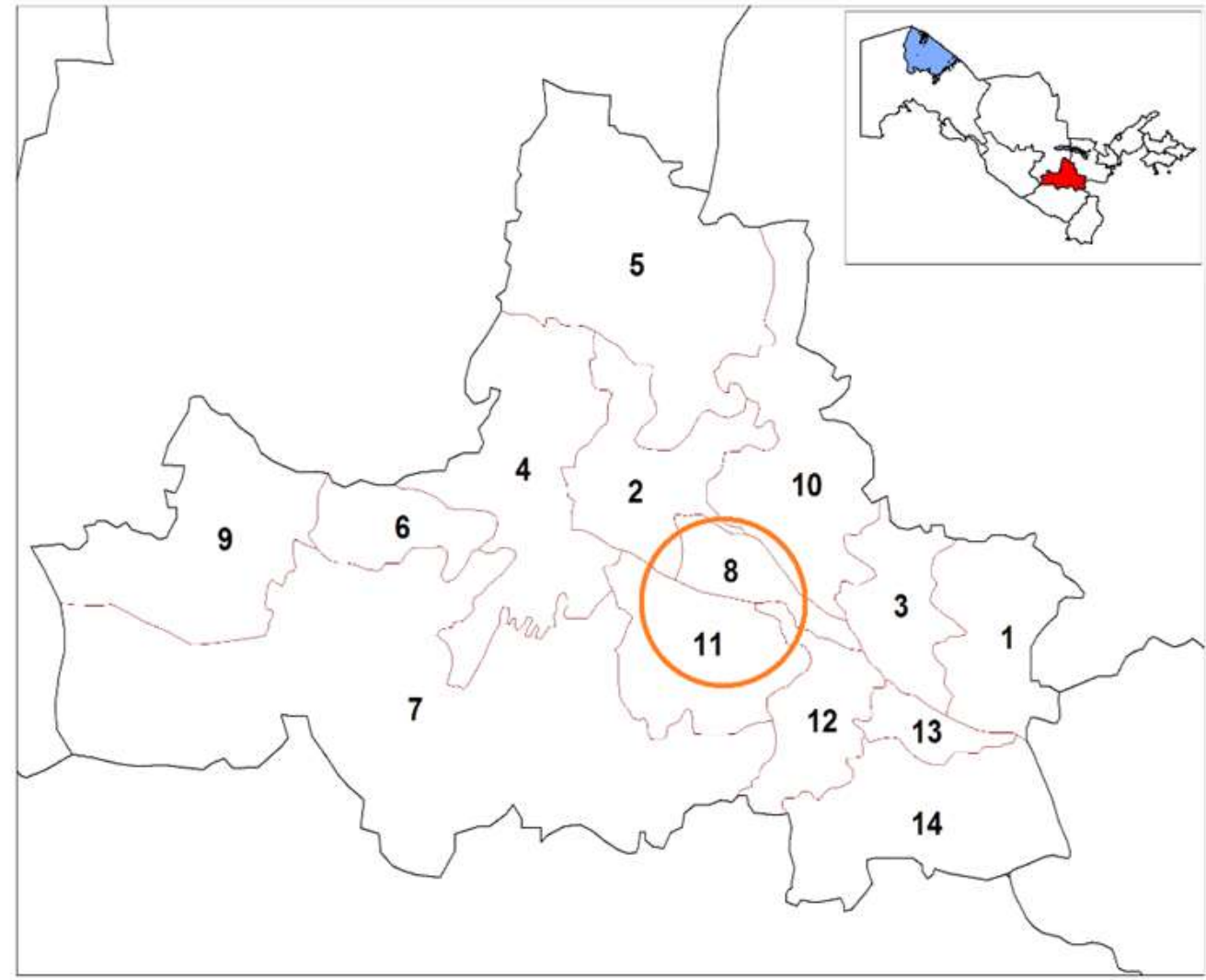

Figure 4. The area where the object of scientific research is located

Table 1

Classification of variables*

\begin{tabular}{|l|c|c|c|c|}
\hline \multicolumn{1}{|c|}{ Variables } & Average & $\begin{array}{c}\text { Deviation from } \\
\text { the standard }\end{array}$ & Min & Max \\
\hline Profit, million sum & 120.523 & 96.476 & 25 & 380 \\
\hline Information & 1.773 & .743 & 1 & 3 \\
\hline Crop field, hectare & 87.477 & 54.042 & 25 & 258 \\
\hline Labor resource, person & 19.25 & 7.189 & 9 & 43 \\
\hline Investment funds, million soums & 125.909 & 100.312 & 15 & 385 \\
\hline Activity & .477 & .505 & 0 & 1 \\
\hline Network activity & .432 & .501 & 0 & 1 \\
\hline
\end{tabular}

* Source: Social Survey data conducted by the researcher

\section{RESULTS OF THE ANALYSIS}

According to the results obtained (Table 1), in the increase in the profit received from the production activities of farms, the investment amount is increased by 1 percent $(\mathrm{p}<.01)$ statistically significant. That is, 1 unit ( 1 million soums) for the activity of farmer increase the amount of profit received from the activity by 22.6 percent. Despite the fact that, the investment funds involved in the activity are spent on innovation or the digitization of production activities can have an impact on the number of labor resources employed in the activity.

The increase in the amount of profit in the activity of farmers is due to the fact that the information of the head of the farmer and the size of the crop area is also 1 percent $(p<.01)$ statistically important. An increase of 1 unit of information of the head of the farm will increase the amount of profit from activities by 26,9 percent. 


\section{EPRA International Journal of Research and Development (IJRD)}

In addition, the increase of crop areas by 1 hectare in farmer farms increases the profits by 69.6 percent. However, the main activity of farmer Farms is considered livestock 10 percent $(p<.1)$ it is considered statistically significant and increases the amount of profit by 10,1 percent. However, the activity of diversified farms is statistically significant at a change in the amount of profit at $5 \%(\mathrm{p}<.05)$, which contributes to the increase in profit by 15.4 percent.

Based on this obtained result, the marginal effect of the relationship between the dependent variables and the independent variables were determined (Fig. 5).

Table 2

Influence of investment funds on profits derived from farm activities

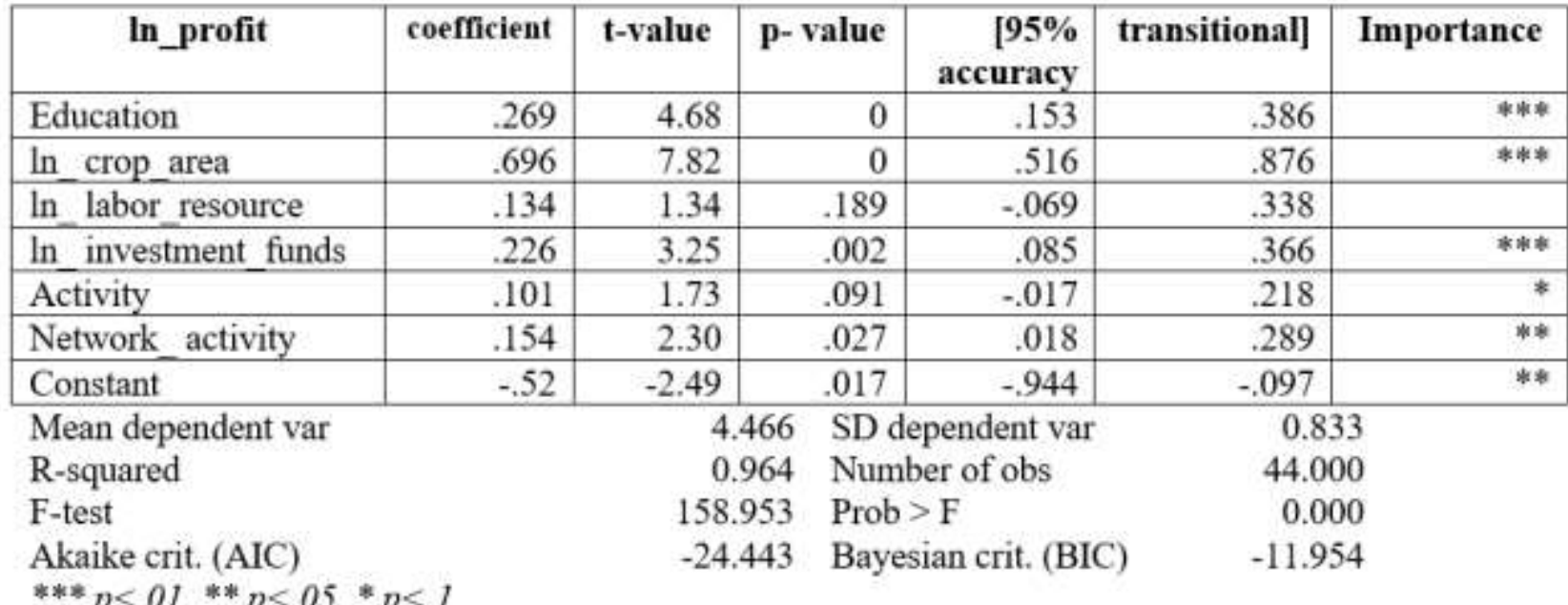

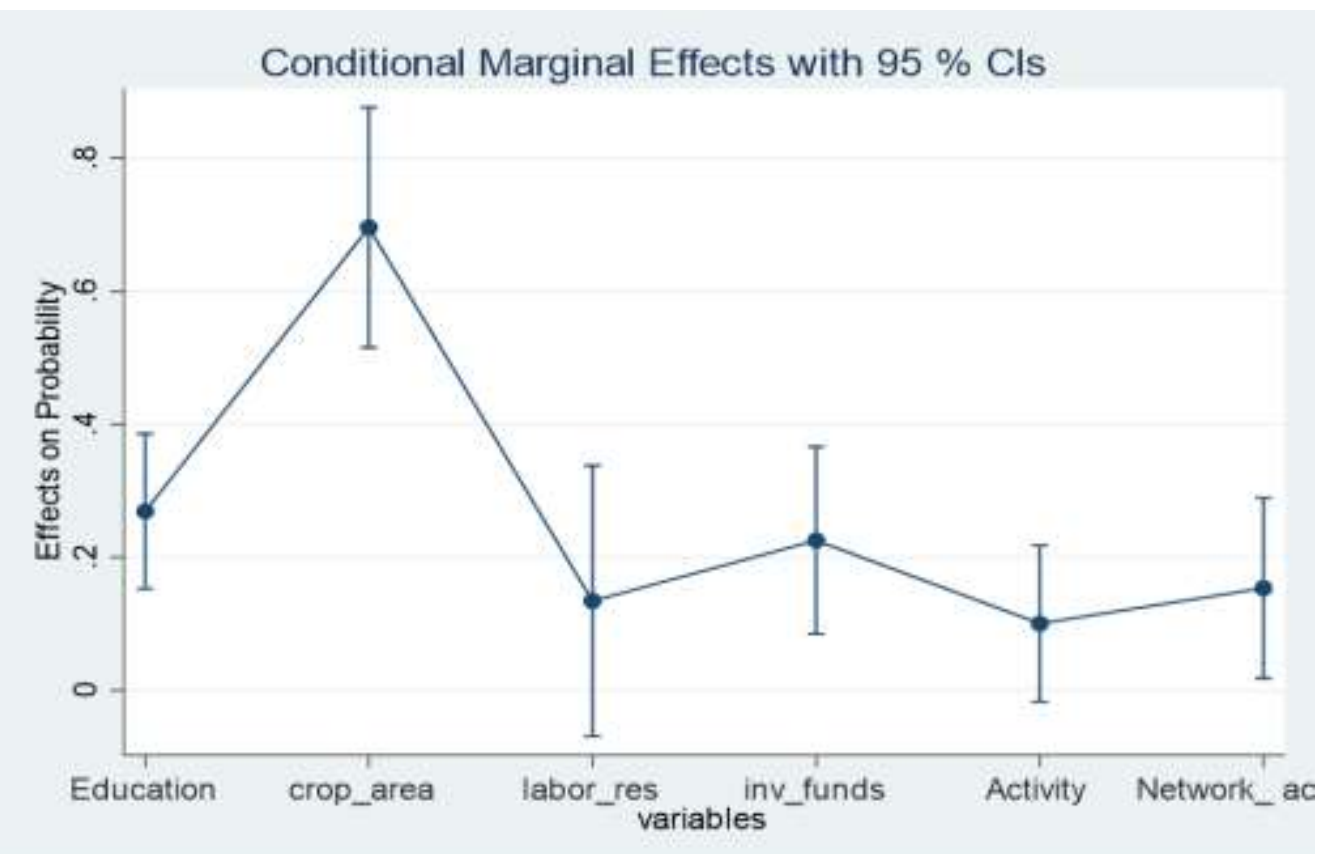

Figure 5. The marginal effect of relationships between variables

The marginal impact level of the independent variables is expressed between 0 and 1 , and the investment amount, farm data, and the area of the crop are statistically significant at 1 percent $(p<.01)$ of the amount of profit received from farm activities. The predicted value of these variables in the change in the amount of profit on farms is in the range of $\pm 0.05-0.08$, which affects the increase or decrease in profit. 


\section{CONCLUSION AND RECOMMENDATIONS}

In our country, agricultural activity plays an important role in meeting the demand of the population for food products, increasing the income of the rural population, providing ensuring labor-intensive employment. Investment funds are important for the sustainable development of this sector, increasing production, the formation of diversified activities.

Over the past 5 years, the investment funds included in the main capital in the activities of agriculture, forestry and fisheries have increased. However, in the sources of investment, the budget funds of the Republic decreased and foreign investment funds increased by an average of 40-42 percent.

The relationship between investment funds and the amount of profit received from the activities of farmer is statistically significant at 1 percent. In the future, increasing the amount of investment involved in the farm activity by 1 unit will increase the amount of profit received from the activity by 22.6 percent.

It is necessary to pay attention to the factors that are statistically significant in increasing the amount of profit derived from the activities of investment funds attracted by the government to agricultural activities. That is, it is necessary to increase the volume of investment funds spent on the organization of diversified farmer economic activity, which is relatively large in the area of crop. It is also possible to give opportunities for attracting investment funds in the expansion of production capacity by improving the skills of farm managers, their knowledge.

\section{REFERENCES}

1. World Bank. (2007). Philippines: agriculture public expenditure review. Technical working paper 40493. Washington, $D C$.

2. Lowder S. K., Carisma B., Skoet J. (2012). Who invests in agriculture and how much? An empirical review of the relative size of various investments in agriculture in low-and middle-income countries.

3. Makhmudov S. (2020). Investitsiyalarni moliyalashtirishda investitsion muhitini takomillashtirish. Arhiv nauchnyx issledovaniy. T. 35.

4. Yusupov M. (2020). Markazlashgan davlat investitsiyalari va maqsadli dasturlari orqali qishloq xo 'jaligini rivojlantirishning ustuvor yo'nalishlari. Arxiv nauchnyx issledovaniy, №. 10.

5. Schmidhuber, J. \& Bruinsma, J. (2011). Investing towards a world free of hunger: lowering vulnerability and enhancing resilience. In A. Prakash, ed. Safeguarding food security in volatile global markets. Rome, FAO

6. Hotamov I. (2020). Investitsiya loyihalari tahlilining asosiy yo "nalishlari. Arxiv nauchnyx issledovaniy. №. 11.

7. O'zbekiston Respublikasi Prezidentining Farmoni. O'zbekiston Respublikasi moliya vazirligi huzuridagi qishloq ho jaligini davlat tomonidan qo'llabquvvatlash jamg'armasi faoliyatini takomillashtirish to'g'risida. PF - 6179 - son. 26.02.2021. https://lex.uz/docs/5309649
8. O'zbekiston qishloq xo 'jaligi. O'zbekiston Respublikasi davlat statistikasi qo 'mitasi. Toshkent, 2020. 